\title{
How Do Smuggling and Trafficking Operate via Irregular Border Crossings in the Middle East?
}

\author{
Evidence from Fieldwork in Turkey
}

Ahmet Içduygu and Sule Toktas*

\begin{abstract}
This article summarizes main trends, issues, actors, and activities regarding the operation and extension of human trafficking and smuggling via irregular border crossings in the Middle East. Its premise is that rather than the obvious involvement of hierarchical mafia-type organized crime groups, globally articulated networks of locally operating independent, individual groups comprise the essential foundation for human trafficking and smuggling in the region. The available empirical evidence first suggests that elaborating on various aspects of human trafficking and smuggling is a delicate task and any consideration of priorities for data collection and analysis on these activities must start with a clear idea of the information needed and how to obtain that information. Given the highly sensitive nature of trafficking and smuggling issues, there is no simple research practice that can satisfy all these concerns. It is within this context that our analysis here only offers some partial explanation of the complex nature of human trafficking and smuggling in the Middle East. The data used here provide, to the best of our knowledge, the first primary, reliable, and representative information on traffickers and smugglers as they come directly from the narratives of the traffickers and smugglers interviewed.
\end{abstract}

Evidence from our fieldwork in Turkey during the last five years indicates that the ongoing pattern of human trafficking and smuggling in the region is the outcome of quite complex interactions among locally operating individuals

\footnotetext{
* Department of Political Science and Public Administration, Bilkent University, Turkey.
} 
and groups, with the simultaneous and sequential operation of a variety of interacting factors, including the presence of interpersonal trust relations between human traffickers and smugglers and the migrants, and the existence of national-, ethnic-, kinship-, friendship-based networks spanning countries of origin, of transit, and of destination worldwide. The study has confirmed that the nature of trafficking and smuggling in the Middle East is quite different from similar activities found elsewhere in the world. Nevertheless, the study concludes that we should not disregard these issues from the perspective of criminal justice and human rights.

\section{INTRODUCTION}

Over the past ten years, irregular border crossings have emerged as a new major element in international migratory flows throughout the world. There is no doubt that the smuggling and trafficking of human beings is an essential part of these movements. Corresponding to their increasingly disturbing nature, the issues of irregular migration and human trafficking and smuggling elicit widely different responses from various observers. As noted by Salt (2000a: 3), human trafficking and smuggling have the capacity to excite attention and polarize opinions. Some believe these actions to be among the inevitable consequences of the globalized dynamics of contemporary human mobility (Içduygu and Keyman, 2000: 383384; Içduygu and Ünalan, 2002: 3-6), while others see them as serious illegal activities in the hands of organized criminal groups (IOM, 2000: 8-11; SMOFA, 2001). ${ }^{1}$ Others claim that as migrant-receiving countries tighten their legal immigration channels, the only way for many potential migrants to enter these countries is through irregular border crossings, often with the help of smugglers and traffickers (Graycar, 2000; Içduygu, 2000: 358; Salt, 2000b: 32). It would seem not only that our scholarly or public attitudes toward irregular migration, smuggling, and trafficking differ, but that there is no settled view on the solution.

There are a variety of studies that focus empirically on irregular migration. ${ }^{2}$ However, a good deal of the literature on human trafficking and smuggling is not really entirely empirical; it often consists of various anecdotal evidence and tends to be descriptive. For instance, claims of the increasing involvement of organized criminal groups in smuggling and trafficking have attracted considerable attention and concern at an international level, yet details on the nature of the criminal involvement in transnational people smuggling and trafficking are not easy to obtain (Tailby, 2001). An empirical analysis of these issues requires answers to the following questions: (1) what is meant by the terms "smuggling" and "trafficking"? (2) who facilitates these activities? (3) do these activities amount to organized crime or something else? In this article, we bring together empirical and analytical findings to argue that such a comprehensive approach to better understand the dynamics and mechanisms of human smuggling and 
trafficking is possible. In considering these questions, we rely directly on the three field studies conducted on the irregular transit Middle Eastern migrants in Turkey during the past five years.

In fact, Turkey plays a pivotal role in Middle Eastern-originated irregular migration. It was not until the 1990s that Turkey became a major country of transit for thousands of irregular migrants mainly from Middle Eastern countries such as Iran and Iraq. Since then, however, many have come to the country via the services of smugglers and traffickers. Turkey constitutes an ideal case study to address the smuggling and trafficking issues encountered in the wider nexus of the Middle Eastern, Mediterranean, and European regions because of Turkey's high rate of irregular migration between the Middle East and Europe, its role as a producer of irregular migrants of its own, and its long established emigration experience with the international migratory regimes in Europe in general. These three aspects are essential in exploring the nature of human smuggling and trafficking in the region.

Most studies on human smuggling and trafficking issues have either taken a narrow, country-specific focus or have had a very loose, broad approach. This article differs in its focus on an inclusive geographical region - Turkey and the Middle East; in its use of first-hand data collection on smugglers and traffickers from field work in Turkey, rather than secondary data use; and in its methodological dimension in general. The focus is regional because we view the geographical basis of irregular migration as the aggregation of a multitude of networks in local communities as well as in wider settings. We will also see, however, that local communities are profoundly influenced by powerful actors who integrate the localities into the globalized world, thus provoking local networks to function both locally and globally.

A whole series of geographical factors in this decade have reinforced the key role that Turkey and the Middle East have played in human smuggling and trafficking since the early 1980s. It is widely argued that increasing economic disparity, continuing wars, civil conflict, and human right violations, and growing access to communications and transport networks over the last two decades have led to the significant increase in the numbers of irregular migrants and asylum seekers moving out from the Middle East and travelling through Turkey and attempting to arrive in Europe and other parts of the developed world. The recognition of human smuggling and trafficking from Turkey and the Middle East has become increasingly apparent with tragic stories covered almost daily by the media around the world. This is also indirectly ${ }^{3}$ evident in the United Nations High Commissioner for Refugees (UNHCR) statistics on asylum seeking in Europe: for instance, in 2000 there were more than 90,000 asylum seekers coming to Europe from the three countries of the Middle East - Iran, Iraq, and Turkey - accounting for more than one-fifth of the total asylum seekers to the continent (Içduygu, 2001). 
The first part of this article discusses the concepts of "smuggling" and "trafficking". The second part gives an overview of the irregular migration flows in the region, particularly referring to the case of transit migration flows through Turkey that originate from the Middle East and head to developed countries. After presenting the specifications of our data collection in Turkey on human smuggling and trafficking, the fourth part of the article focuses the question of how smuggling and trafficking activities operate via irregular border crossings in Turkey and the Middle East. The article concludes with a discussion of the nature of human smuggling and trafficking in the region, in particular by determining whether all these smuggling and trafficking activities are mostly organized by criminal organizations or occur in some other way.

\section{SMUGGLING ANDTRAFFICKING: ACONCEPTUAL CLARIFICATION}

Typically, human trafficking and smuggling are distinctly defined (Salt, 2000b:33; Shelley, 2001: 1; SMFOA, 2001: 5; Tailby, 2001: 2). Human trafficking is considered the transportation of people from one place to another for exploitative purposes through coercion, deception, or some other form of illicit influence, while human smuggling is associated more with illegal border crossings under the assistance of third parties (Juhász, 2000: 170; Okólski, 2000: 60; Salt, 2000b: 34; Shelley, 2001: 1; Skeldon, 2000: 8-9). The United Nations Convention Against Transnational Organized Crime (TOC) elaborates the distinction between human trafficking and smuggling with two supplementary protocols. Thus, the Protocol to Prevent, Suppress and Punish Trafficking in Persons, especially Women and Children defines trafficking as follows:

Trafficking in persons shall mean the recruitment, transportation, transfer, harbouring or receipt of persons, by means of the threat or use of force or other forms of coercion, of abduction, of fraud, of deception, of the abuse of power or of a position of vulnerability or of the giving or receiving of payments or benefits to achieve the consent of a person having control over another person, for the purpose of exploitation. Exploitation shall include, at a minimum, the exploitation of the prostitution of others or other forms of sexual exploitation, forced labour or services, slavery or practices similar to slavery, servitude or the removal of organs.

The Protocol against the Smuggling of Migrants by Land, Sea and Air defines smuggling as:

(...) the procurement, in order to obtain, directly or indirectly, a financial or other material benefit, of the illegal entry of a person into a State Party of which the person is not a national or a permanent resident (Art. 3).

Drawing upon these classifications, trafficking differs from smuggling in two points. First, exploitation is a fundamental element of the various phases of 
trafficking whereas the foremost characteristic of smuggling is not exploitation. Second, although smuggling suggests itself as the illegal entry of a person into a foreign country encompassing an aspect of international migration, human trafficking does not necessarily involve border crossing.

However, there is still ambiguity regarding the meaning and use of the terms "trafficking" and "smuggling" as well as those of the actors involved, the "trafficker" and the "smuggler", each term being determined by the particular context in which it is used. Also, there may be instances where the terms are used indiscriminately and/or overlap. These instances may produce complexities in determining the concrete stipulation of human rights violations or exploitation (Salt, 2000b: 34), the duration and the degree of the involvement of the third parties in the process (Skeldon, 2000: 6), and the connection with the border crossing (Tailby, 2001:3). Trafficked migrants are often exposed to exploitation in terms of their labour and human dignity, with women and children being particularly vulnerable to sexual exploitation (IOM, 2000: 8; Juhász, 2000: 170; Salt, 2000b: 34; SMOFA, 2001: 4).

Not only traffickers, however, expose the migrants to abuse and human rights violations. Smugglers, who are instrumental in facilitating the illegal crossing of borders, are not above committing human rights violations themselves, which may take the form of rape, physical and mental abuse, food deprivation, and abandonment and death (IOM, 2000: 6). In addition, although human smuggling is considered to entail the short-term involvement of smugglers whose function terminates after the smuggled people reach their destination (IOM, 2000: 6-7), there may also be occurrences that pose vagueness to the time interval; that is the involvement of smugglers in the smuggling chain may endure for long periods of time. Furthermore, human trafficking is a course of action that does not necessarily require but may involve border crossing, and human smuggling may cover the movement of persons within national borders as well (Tailby, 2001:3). This complexity, highlighted in aspects of migration, is considered to pose a challenge to traditional migration theories, blurring the boundaries between human trafficking and smuggling (Salt, 2000b: 35).

Given their specifications above, human trafficking and even smuggling are often visualized as a global business involving well-organized criminal, mafia-type formations involving countries of origin, of transit, and of destination worldwide. They often exist as a business driven by the demand for illegal entry channels as migrants find themselves blocked by increasingly stringent entry controls and diminishing opportunities for regular migration. However, at the other end of the spectrum of legal controls are their very own respective shortcomings, such as continuing porous borders, corrupt border officials, shortages of funds and technical and human resources, as well as the sheer impossibility of effectively patrolling long borders and, in particular, long coast lines. In that, Turkey is no exception. 
In this study, we mainly argue that all along the migrant trafficking and smuggling chain, numerous individuals intervene to accomplish specific aspects of the trafficking process - individuals who are not familiar with each other and who change as circumstances demand. There seem to be locally operating individuals who are a part of globally working trafficking and smuggling networks spanning countries of origin, of transit, and of destination worldwide. Even nationality, kinship, or friendship is part of this networking.

As for the migrants trafficked, they are beholden to their traffickers through their vulnerability and their dependence on them to realize their migration objectives, while remaining exposed to dire potential consequences in terms of apprehension by immigration or police authorities or even their own demise if they should become stranded. The extent of their desire to migrate and their desperation and vulnerability are the strength and backbone of the trafficking business and these factors ensure their continuing operations and tremendous profits. According to one estimate, the global profit margin in human trafficking and smuggling is around US\$5 to \$7 billion per annum (Di Nicola, 1999: 3).

The ambiguity attached to the use of these terms mainly results from the general lack of sufficient and reliable data on human trafficking and smuggling because of the "irregular" and "illicit" nature of these types of migration. Hence, collection of primary data on traffickers and smugglers is important to achieve (Salt, 2000b: 37).

In this study, the people involved in human trafficking and smuggling activities through Turkey have been interviewed. Due to the reasons discussed above, this study found that the categories of "human smuggling" and "trafficking", and therefore "trafficker" and "smuggler", by and large overlap one another. As the roles that human smugglers and traffickers perform are discussed in the article, the case relevant for Turkey seems to be more consistent with the characteristics of smuggling. However, this does not mean that this type of human smuggling does not entail any characteristics of human trafficking; rather it seems that human smuggling from time to time becomes articulated to human trafficking.

\section{A BRIEF OVERVIEW OF IRREGULAR MIGRATION INTURKEY}

In the last two decades Turkey has increasingly been confronted with largescale movements of irregular migrants, mainly coming from the Middle East, who use Turkey as a transit area on their way to Europe. This relatively new migration phenomenon has a number of political, social, and economic implications, not only for Turkey, but also for the wider context of the East-West and South-North migration axes, particularly for migration from the Middle East to Europe. 
Irregular migration flows to Turkey introduce three main groups of immigrants to the country (Içduygu, 2001). The first involves the migration of foreigners mostly from the Eastern European countries (such as Romania and Moldavia), who arrive in Turkey in search of jobs. For instance, some Turkish farmers and industrialists in the western regions of the country are increasingly relying on Eastern European labour migrants. Similarly, countless middle and upper class families employ domestic help, mainly Moldavian women. Many of these migrants entered Turkey legally but subsequently overstayed or failed to get their visas renewed. The second form of irregular migration to Turkey involves transit migrants who come to Turkey mainly from the Middle East (mostly Iranians and Iraqis) and from various Asian (e.g., Pakistan, Bangladesh, and Sri Lanka) and African (e.g., Nigeria, Somalia, and the Democratic Republic of the Congo) countries. These migrants perceive Turkey as a transit area en route to the developed countries of the West. This group involves migrants who both enter and leave the transit country illegally and those who have overstayed their visa entitlement. The third group of irregular migrants comprises the rejected asylum seekers who are reluctant to return home. They are normally on the lookout for opportunities to earn money and the possibility to migrate to a third country.

It appears that three principal factors contributed to transforming Turkey into a migration transit zone. First, political turmoil and conflicts in neighbouring areas in the Middle East have pushed people out of their countries in search of security and better prospects. Second, Turkey's geographical position at the intersection between East and West, and South and North, makes it an attractive transit zone for those intending to reach Western and Eastern countries. Third, the increasingly stringent entry requirements and reinforced border controls, as well as sophisticated electronic surveillance systems introduced by Western countries to control and combat irregular migration, have diverted migration flows from Europe to peripheral countries, such as Turkey. As a result of these factors, Turkey constitutes a useful case study regarding the wider irregular immigration issues encountered in Europe.

In recent years, it has been well documented that the four main sea routes used in the irregular migratory regime in the south of Europe operate: (a) from the Maghreb directly to the southern coast of Spain, or via Melilla and Ceuta; (b) from Turkey to Greece, Sicily, or mainland Italy; (c) from the south-eastern Adriatic coast to Italy and especially Puglia; and (d) from Egypt (or the Maghreb via Tunisia, sometimes via Malta) to Sicily or mainland Italy (Içduygu and Ünalan, 2001; Pugh, 2001: 8). Among these four main routes, thousands of irregular migrants from the Middle East use the route crossing through Turkey. Besides these maritime routes, many migrants are being smuggled and trafficked from the Middle East to Europe via air and land routes in Turkey. The use of these transportation axes varies, with sea travel having recently become the most frequently used mode of transport, followed by land and air. 
One of the few studies on irregular migration in this region, the 1995 International Organization for Migration (IOM) Study of Transit Migration in Turkey, concluded that Turkey was increasingly becoming a country of irregular migration movements. This study indicated that these irregular transit migrants were mostly young men from Iran and Iraq, migrating for economic reasons and had come to Turkey with the help of smugglers and traffickers. Only 8 per cent of those interviewed envisaged the possibility of a permanent stay in Turkey (Içduygu, 2000: 364). Rather, their intentions to go either to Europe, or one of the traditional immigration countries such as Australia, Canada, or the United States, was quite clear and they were planning to use smugglers and traffickers to help them reach their final destinations.

There was some evidence pointing to a fairly long transit migration process, involving considerable costs. It was estimated that, on average, a transit migrant in Turkey had typically already spent one year en route between his first departure and his arrival in Turkey, spent nearly two years in Turkey, and was planning to depart for the final destination in another year. The overall cost of travel to Turkey for a single transit migrant was around US\$990 and the cost from Turkey to the final destination was estimated at around US\$2,800. A large portion of these sums was paid to smugglers and traffickers. However, the 1995 study had shown that these people had not been trafficked into Turkey against their will, but had decided to leave their homes on their own accord for mainly economic considerations. However, they had sought the assistance of smugglers and traffickers to move from one point to another along their migratory route.

Apart from the 1995 IOM study and a few other studies based on it (see Kirisçi, 2001; Içduygu, 2000), no scholarly studies of irregular migration in Turkey and the Middle East exist, nor is any information available on the subsequent development of such migration flows. ${ }^{4}$ However, frequent media reports indicate that Turkey is still at the centre of irregular migration from the Middle East and that the trend is actually increasing. It is no exaggeration to say that practically everyday media reports refer either to irregular migrants being apprehended in Turkey or to illegal migrants coming from Turkey and landing on the coasts of Greece, Italy, or France. In the absence of reliable quantitative and qualitative sources of information on irregular migration in the Middle East and Turkey, such media reports, which were compiled by the authors, provide some interesting incidental information to sketch a picture of the dynamics of illegal entries/departures and transit migration in Turkey over the last five years. From these media reports, it is possible to infer the following: (1) it is difficult to tell whether the authorities are becoming stricter or the flows are increasing, or both; (2) entry points to Turkey are mainly on the Iranian and Iraqi borders - Van province is a well-known example. The departure points are often in the western part of the country, mainly in the coastal areas such as the provinces of Istanbul and Izmir or close to the border with Greece, such as Edirne province; (3) those entering Turkey illegally arrive mainly from two neighbouring countries, Iran and 
Iraq, but also from a wide range of others such as Bangladesh, Ghana, Nigeria, Pakistan, Algeria, Afghanistan, Sri Lanka, India, Palestine, and Azerbaijan; (4) some Turkish citizens, in particular Turkish citizens of Kurdish origin, join the transit migrants from other countries to find their way to the West; (5) smugglers and traffickers facilitate the migratory process of the migrants, who use them of their own accord; (6) the amount of money paid to smugglers and traffickers varies between US $\$ 1,000$ to $\$ 7,000$ depending on the case; (7) migrants generally arrive in Turkey by foot or by car, bus, or truck and leave Turkey by foot, by truck, and by sea - with sea travel gaining in importance; (8) migrants usually spend less than a year from their departure point to the final destination point; and (9) the problem of illegal entries/departures and transit migration in Turkey has begun to be widely recognized by both national and international authorities.

Subject to the above caveat regarding the reliability of available information, Table 1 gives an indication of the number of irregular migrants apprehended by the Turkish authorities over the past five years and the sharp increase recorded during that period. From 11,000 irregular migrants apprehended in 1995, the figure had risen to more than 29,000 by 1998. In 1999 it had reached more than 47,000 and had nearly doubled to 94,000 by 2000 . These numbers may be viewed as indicative of both increased numbers of irregular migrants entering Turkey and of improved methods of control and apprehension applied by the Turkish authorities. Concerning the composition of irregular migrants apprehended, the majority came from Iraq (23\%), followed by Iranians (6\%) and Afghans (6\%). Migrants from Bangladesh, Pakistan, and India together accounted for 14 per cent. Eight per cent of the migrants were from the former Soviet Republics. The latter group also accounts for the largest number of overstayers and illegal labourers (see Table 1).

\section{DATA}

The data primarily utilized in this article, which mainly deal with smuggling and trafficking activities, come from three different field studies conducted in Turkey during the last five years. The first fieldwork ${ }^{5}$ in this context was done in Istanbul, the biggest metropolitan province in Turkey, which is the main departure station for irregular migrants, and Ankara, capital city of the country where a considerable number of asylum seekers were located in 1998-1999. This work included structured in-depth interviews with 50 irregular migrants. The second fieldwork ${ }^{6}$ was conducted in Istanbul and Van, a province bordering Iran and hosting many Iranian and Iraqi irregular migrants arriving in Turkey in 2001. In this field study, 53 irregular migrants and eight smugglers and traffickers were interviewed face-to-face. The last fieldwork ${ }^{7}$ was done in Van in 2002. In this final study, within the format of on-site observation and inquiry, village communities bordering Iran were systematically observed and villagers who are supposedly involved in smuggling and trafficking activities were interviewed. In 
all three studies, relevant public officials involved in combating human trafficking and smuggling activities in the country were also interviewed.

TABLE 1

IRREGULAR MIGRATION IN TURKEY, APPREHENDED CASES

\begin{tabular}{|c|c|c|c|c|c|c|c|c|}
\hline $\begin{array}{l}\text { Country of } \\
\text { origin }\end{array}$ & 1995 & 1996 & 1997 & 1998 & 1999 & 2000 & 2001 & Total \\
\hline Afghanistan & 24 & 68 & 81 & 921 & 3,046 & 8,476 & 9,542 & 22,158 \\
\hline Albania & - & 1 & & 9 & 792 & 1,026 & 1,461 & 3,289 \\
\hline Algeria & 27 & 25 & 69 & 207 & 102 & 430 & 429 & 1,289 \\
\hline Armenia & 4 & 2 & & 1 & 98 & 474 & 491 & 1,070 \\
\hline Azerbaijan & 21 & 3 & 3 & 10 & 620 & 2,262 & 2,201 & 5,120 \\
\hline Bangladesh & 113 & 322 & 301 & 2,408 & 1,193 & 3,228 & 3,771 & 11,336 \\
\hline Bulgaria & 21 & 22 & 39 & 103 & 1,005 & 1,699 & 2,108 & 4,997 \\
\hline Egypt & 4 & 12 & 99 & 29 & 94 & 382 & 319 & 939 \\
\hline Georgia & 37 & 9 & 9 & 5 & 809 & 3,300 & 3,570 & 7,739 \\
\hline Germany & - & 1 & 1 & - & 372 & 629 & 579 & 1,582 \\
\hline India & 2 & 25 & 18 & 102 & 189 & 779 & 897 & 2,012 \\
\hline Iran & 252 & 362 & 364 & 1,116 & 5,281 & 6,825 & 8,504 & 22,704 \\
\hline Iraq & 2,128 & 3,319 & 5,689 & 14,237 & 11,546 & 17,280 & 23,444 & 77,643 \\
\hline Macedonia & 1 & - & 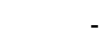 & - & 439 & 488 & 460 & 1,388 \\
\hline Moldavia & 19 & - & 17 & 5 & 3,098 & 8,290 & 7,980 & 19,409 \\
\hline Morocco & 28 & 53 & 93 & 295 & 369 & 1,401 & 1,905 & 7,033 \\
\hline Nigeria & 1 & 20 & 30 & 84 & 137 & 450 & 419 & 2,356 \\
\hline $\begin{array}{l}\text { Other - } \\
\text { unknown }\end{array}$ & - & - & - & - & 2,028 & 3,289 & 361 & 5,678 \\
\hline Pakistan & 708 & 435 & 307 & 1,798 & 2,650 & 5,027 & 5,618 & 16,543 \\
\hline PRC & & & & 1 & 115 & 545 & 731 & 1,392 \\
\hline Romania & 68 & 12 & 107 & 36 & 3,395 & 4,500 & 4,533 & 12,651 \\
\hline Russia & 5 & 4 & 52 & 2 & 1,695 & 4,554 & 4,694 & 11,006 \\
\hline $\begin{array}{l}\text { Sierra } \\
\text { Leone }\end{array}$ & - & - & - & 20 & 42 & 462 & 370 & 894 \\
\hline Stateless & - & - & - & & 61 & 322 & 315 & 698 \\
\hline Syria & 78 & 86 & 144 & 476 & 776 & 1,399 & 1,293 & 4,252 \\
\hline Tunisia & 3 & 48 & 81 & 44 & 76 & 255 & 297 & 804 \\
\hline Ukraine & 9 & 4 & 17 & 4 & 1,715 & 4,527 & 4,401 & 10,677 \\
\hline $\begin{array}{l}\text { United } \\
\text { Kingdom }\end{array}$ & - & 2 & & 4 & 233 & 643 & 442 & 1,324 \\
\hline Uzbekistan & 1 & 1 & - & - & 142 & 587 & 486 & 1,215 \\
\hline Yugoslavia & 13 & - & - & - & 325 & 1,283 & 1,443 & 6,340 \\
\hline Total & 11,362 & 18,804 & 28,439 & 29,426 & 47,524 & 94,514 & 92,364 & 322,438 \\
\hline
\end{tabular}

Source: Directorate of Security of the Turkish Republic Ministry of Interior, 2001. 
In order to gain a better picture of trafficking and smuggling activities in Turkey in the wider context of Middle East, this article mainly relies on primary data obtained during face-to-face interviews conducted with smugglers and traffickers in 2001, and secondary data of personal statements made by apprehended smugglers and traffickers as recorded in police reports. Based on eight face-to-face interviews with some smugglers and traffickers and five police reports, it is possible to obtain a general outline of the smuggling and trafficking business in Turkey. These accounts, together with the data obtained from the fieldwork in 1998-1999 and in 2002, are used to determine the categories of human smugglers according to the role they perform, the routes and techniques they use, and the business terms involved in the transactions between the migrants and the smugglers. In addition, we address whether human smuggling is a large, mafia-style operation.

\section{HUMAN SMUGGLERS ANDTRAFFICKERS: HOW THEY OPERATE}

In this part, reflecting upon the findings obtained in the three field studies, a typology of smugglers and traffickers will be developed in accordance with the roles they perform in human trafficking and smuggling. This typology will help to illuminate the processes of human trafficking and smuggling and will clarify how the "business" in general operates. The ambiguity concerning the nature of human trafficking and smuggling, that is whether it is a systematically organized and centralized crime resembling a mafia-type organization, or it is a more loosely organized network of relations which is predominantly a function of ethnic/kin relationships, will also be addressed. In addition, the working of the network in human smuggling and trafficking will be discussed with a special focus on its adjustment to technological developments and the terms of payment.

\section{Human trafficking and smuggling: the actors involved}

The roles performed by traffickers and smugglers in the processes of human smuggling and trafficking are varied and sometimes may overlap one another (Schloenhardtt, 1999: 18-20; Graycar, 2000: 10-11; UNICRI and AIC, 2000: 6). To illuminate the functioning of trafficking and smuggling, various researchers refer to the presence of ten different categories of traffickers according to the roles they perform: (1) arranger/investor: invests money in the trafficking operation and oversees the whole organization and its activities; (2) recruiter: works as a middleman between the arranger and the client of the criminal transaction; (3) transporter: in charge of assisting the migrants in leaving the country of origin by land, air, or sea; (4) corrupt public officials/ protectors: protect the criminal organization by abusing their position, status, privileges, and committing other violations of the law; (5) informers: manage the information flow and have access to well-organized and centralized 
communications systems through sophisticated technology; (6) guides and crew members: responsible for moving illegal migrants from one transit point to another or helping the migrants to enter another country by whatever means; (7) enforcers: responsible for controlling collaborators and migrants and for maintaining order, often involving violence; (8) support staff and specialists: locals stationed at transit points who support the organization by providing accommodation and other assistance to illegal migrants; (9) debt collectors: responsible for collecting the trafficking fees in the destination country; and (10) money movers: person who arranges for the laundering of the proceeds of crime and for disguising their origin through a string of transactions or investing them in legitimate businesses.

In this study, seven interconnected and sometimes overlapping categories of smugglers have been determined. Although some of the categories developed in this study show similarities with those of Schloenhardtt (1999), they unveil the more disorganized and spontaneous nature of human smuggling compared with the organized criminal network of human trafficking. The characteristics of smugglers and traffickers developed in this study are as follows:

1. Local initiating smuggler: organizes the departures of irregular migrants from their localities and takes them from the previous smuggler and hands them over to another one in order to facilitate the illegal border crossing.

2. Cashier: as an entrusted person, receives and pays out money between the migrants and smugglers in the smuggling operation.

3. Guide: knows the region or the borders very well and accompanies the migrants following the agreement between the smuggler and the migrant.

4. Local transiting smuggler: takes the migrants from the border areas in the transit country and moves them to the departure areas in transit country.

5. Middleman: takes the migrants from the person who brought them to the departure point to the next smuggler in the chain (usually landman, shipman, or airman) who arranges the final trip to the point of destination.

6. Landman, shipman, or airman: arranges the irregular border crossings, sea or air passages, and organizes the port from which the migrants will depart and for the bribing of port employees at the point of exit.

7. Other intermediaries, handymen, and other helpers: involved in diverse activities, help all other smugglers and perform secondary roles in human smuggling but not included in above-mentioned categories.

\section{Local initiating smuggler}

Case representing local initiating smuggler; male, Turkish Kurd living in Van, 37 years old, incomplete university education; from face-to-face interview:

In this region, smuggling is part of our economy. If it weren't for animal husbandry and smuggling, the people in this region would not have survived for centuries. Smuggling is a way of life here and is not something negative. 
Being a doctor or an engineer is no different from being a smuggler. My father and my grandfather were in the smuggling business as well. They were smuggling every kind of goods from Iran to Turkey.

Smuggling is the basis of the region's economy. Everything you can imagine travels over the border. You just have to ask for it...In a system like this, it makes no difference if we are carrying spare car parts, diesel fuel, or people. The fundamental rule of capitalism operates here; it is a matter of supply and demand. On the thousand-year-old Silk Road, whatever item needed is smuggled. At that time, the borders there we have now did not exist. Travelling that route was not considered as smuggling. There were only different taxes at different stops. But now on paper they say this is Iraq, this is Iran, this is Turkey and it is illegal to cross without notification...My relatives on the other side of the border are larger in number than the ones on this side of the border. I live in Turkey but more than half of Khvoy, Iran, is my kin. This kind of a relationship is an advantage for all sorts of smuggling, including the smuggling of people. It works like an insurance system.

As the above case illustrates, people-smuggling in this region is often based on a network of social and economic relationships. The local initiating smuggler transports people in the same way he transports goods - anything with an economic value. The smuggler transfers the goods he carries to another smuggler who is usually a relative from the same family/tribe/ethnic group. There are several local smugglers who work through the network of ethnic groups located on either side of the border.

An Afghan, Iranian, or Iraqi who wants to leave his country first gets in touch with a smuggler from his own family/tribal network. Bargaining takes place with the local smuggler. The deal could involve both the crossing of the border, as in the case of border smuggling, or reaching a particular destination in the transit country. The price varies depending on the distance and the difficulties involved in reaching the final destination. The money is handed over to the smuggler or a designated third party trusted by both sides, for instance a cashier. Once his part of the operation has been accomplished, the local smuggler transfers the migrant to the next, together with the money received from the migrant after taking his cut. When the money is paid in advance to a third party, the local smuggler receives his cut of the deal once the migrant has reached the destination. In the case of Afghan migrants, instead of a cash transaction, their property is confiscated by the smuggler who then finances the migration operation. The amounts reported by smugglers and migrants often diverge significantly as migrants tend to overstate and the smugglers to understate the sums involved.

\section{Cashier}

Case representing cashier; Turk from Iraq, 40 years old, university graduate, shopkeeper in Istanbul; face-to-face interview: 
Documents such as asylum applications, passports, visas, and all which are supposedly important are in fact all empty talk. Even without these documents, anyone who wants to go to any country in the world can easily do so. All these years I have been travelling, there is almost no country or city that I have not visited. I was caught only once when I was leaving the airport in Turkey. That was because the passports of my wife and my children were fake. They were fake but the visas on them were real. Today I can easily get a real visa on a fake passport. They make fake passports of such good quality that even embassy personnel cannot tell they are fake. But it is also possible to obtain visas through bribery. In the past we have obtained visas through bribery from the German, French, and Bulgarian embassies. There was even a period when the stamps from the German embassy were stolen. Anyone who wanted was given a visa; at a price of course.

I have no ID card, no passport, no nothing. But I have been doing business in this country for ten years. Because I have been through hard times with Saddam, I help those who want to leave Iraq. The Turkmen Association here is a bit "official" so I don't hang out with them. But most of those who arrive know me from before. They come and find me here in Istanbul. I know some trustworthy middlemen and shipmen who do this business. I take the new arrivals to these friends. They can't cheat me. For Iraqis who intend to continue to the west, there is a cashier system. This means that until the end of the journey, the money stays with a trustworthy person, a paymaster. When the migrants reach their point of destination, they call to say they are OK and then the money is paid to the smuggler. I usually play the role of cashier.

Some police constantly get protection money from illegal migrants...Once I informed the station about a police officer who was collecting money from this business...Some middlemen also have connections with the intelligence service, but it is in fact the smuggler at the very top that has the real connections with the intelligence service and the police. They either leave the smugglers in peace in exchange for some money, or they are actually involved in the business. At the moment, the biggest in the business is an Iranian and has links with the intelligence service. This is the way things work. Since you're doing research, I suggest that you see the business on the spot. I will take you from Afghanistan to Paris as an illegal migrant and you can write as we go. If you pay, of course.

As the above case illustrates, among Iraqis the amount agreed upon for the smuggling operation is usually handed over to a third person (cashier/fiduciary) trusted by both sides. In this study, it was found that there are two main things that directly and considerably contribute to the ongoing operation of human smuggling and trafficking: first, interpersonal trust between the smugglers and traffickers and the migrants; second, international networking among the smugglers and traffickers and the migrants that is usually based on nationality, ethnicity, kinship, and friendship. Upon arrival in the destination country, the migrant communicates to the smuggler a previously agreed upon secret code, following which the smuggler can receive his payment from the cashier. This 
serves to ensure that the smuggler does not trick the migrants. The cashier, who could be in any country (e.g., for someone leaving Afghanistan, a relative in the Netherlands could act as the cashier), receives around US\$50 to $\$ 100$ per deal.

\section{Guide}

Case representing guide; male, Turkish Kurd living in Van, 50 years old, primary school graduate; from face-to-face interview:

I was 11 years old when I first crossed the border into and from Iran. I am now 50 years old and I continuously go back and forth. I inherited this work from my father. I bring everything from Iran and take everything there. I carry whatever people ask and want me to carry, except for one thing: "flour" (drugs). Drug smugglers are not interested in the smuggling of people because for them that is small business. Smuggling is done for money. There is big money in drug trafficking but it is the owner of the drug that makes this money, not the carrier. Those in the drug trafficking business do not bother with the smuggling of people, which does not bring in as much money. But all other smugglers, like myself, smuggle everything including people. I am going to start again the smuggling of people and of diesel oil. If they ask for reapers, I ask the Iranians for reapers, they let me know in two days, I go over and load the reapers on four horses and bring them into the country. We bring Mercedes car parts, diesel fuel, or whatever is needed. The market no longer demands the smuggling of sugar and tobacco. There is no more demand for sugar and tobacco. While smuggling, people are now also transported. Those who trust you find you. This could be either one person, it could be 30 . I have smuggled up to 40 people. Nowadays it costs 100 dollars per head to be smuggled into Van (an eastern province in Turkey).

There are middlemen in Iran who tell you to be at 259 on this day, at this time. Two-fifty-nine is the number of the particular border stone. You go and pick them up. The Iranian pays you the money. The smuggler pays the money to the next smuggler. If he is evil, he will later collect extra money from the travellers, but this is no good. The Afghan smuggler knows the Iranian smuggler at the Iran border. The Iranian knows the smuggler at the Turkish border. It continues like this, but the Afghan smuggler would not know the Turkish smuggler, so it is not a continuous chain. In Iran they come from places like Solmaz, Khvoy, and Riza. They enter into Özalp, Saray, and Baskale (towns in eastern part of Turkey).

There were times when I went to a village in Iran to pick up people and times when I took over on this side of the border. During the journey we don't go into counties and city centres. From the nearest border village in Iran, travel time is normally eight to nine hours, but I do the same route in three to four hours. After all, I am an expert. I reach Van (an eastern city of Turkey) at dawn and leave the travellers when I see the first lights of the city or when we reach a neighbourhood in the outskirts of the city. They all know where they will be going. Most have the address of the person they will be meeting in Van. A man who starts off from Afghanistan has the addresses of people he will be meeting 
in Istanbul or in Paris. I don't take care of business after Van. My job is to bring them in from the border.

The guide is someone who is very familiar with the region and the border area. He guides the migrants once agreement has been reached between the smuggler and the migrant and transfers them to the next smuggler on the other side of the border. Today, modern communication technology facilitates their operation, as even a shepherd in the mountains may be presumed to have two GSM numbers. However, that is merely a question of degree, as even before mobile communication systems facilitated their undertaking, parties involved knew how to establish clandestine contact and to keep it out of the public eye, as these are people who are perfectly familiar with the terrain and, when they are not busy smuggling people, they smuggle all sorts of goods between the two sides.

\section{Local transiting smuggler}

Case representing local transiting smuggler; male, Iranian, 33 years old, living in Van, primary school graduate; from face-to-face interview:

I came to Turkey six years ago. I am an Iranian national. I live mostly in Van. I go back to Iran once every two to three months. I make arrangements for illegal migrants to go to Istanbul from Van. I also make other contacts to arrange their trips to other places from Istanbul. It is not easy for people who have migrated illegally from Iran to travel inside Turkey. The police and the gendarmerie have control points everywhere. I take 50 to 60 dollars from them and ensure that they reach Istanbul. I use part of this money to supply them with fake Turkish ID cards. For this, they must provide me with a photograph. When the police or the gendarmerie stop the trucks in which they are being transported, the migrants show these ID cards. Sometimes instead of taking the main roads, I send them on buses that use the secondary roads where few controls are made. I tell them where they have to go in Istanbul and whom they have to contact. I tell my friends in Istanbul that I am sending them three or five people. If some people in Van want to make sure that they safely arrive in Istanbul and if they are willing to pay me 80 to 100 dollars instead of 50 to 60 dollars, I take them to Istanbul myself.

For those who are interested, I can make arrangements to take people from Istanbul to Italy by boat for 1,500 to 2,000 dollars. I call friends in Istanbul with my mobile phone and tell them that I am sending some people who want to go to Italy. I ask for about 100 dollars per person. I also have friends and contacts in Italy. I can even make arrangements for after Italy. I have in my mobile phone the numbers of friends in Italy. If the migrants want to continue to England, France, the Netherlands, or Sweden after they have arrived in Italy, in addition to the 1,500 to 2,000 dollars that they pay between Istanbul and Italy, they have to pay another 500 to 1,000 dollars.

I usually handle the route between Van and Istanbul, but I help the people in establishing contacts for the continuation of their journeys from Istanbul 
onwards. These contacts can even include travelling to far away countries such as Australia and Canada. But as the distance from Turkey gets larger, the money demanded from them for the trip increases proportionally. The costs increase even more if the illegal migrants want to travel safely, for example, with the use of fake passports and visas and if they want to ensure that they will end up safely in the country of destination.

This type of smuggler guides the migrant to the point from which he embarks on his final destination. This departure point is most often Istanbul, but could be Izmir, Edirne, Çanakkale, or another city in the western part of Turkey. Illegal migrants never get lost in these cities, as they are given the names, addresses, and phone numbers of the people they should meet. It is here that they are transferred to the middleman. The preferred means of transportation is by truck in case of road checks along the way - the driver's ID card, license, and other papers are examined, but the cargo is hardly ever checked. In addition, the bribes paid to various security people along the way also ensure that migrants reach Istanbul or other border cities without being caught on the way.

\section{Middleman}

Case representing middleman; Turkish Kurd, 35 years old, living in Istanbul, secondary school graduate; from face-to-face interview:

The smuggling of people is not as complicated as it looks. For instance, they called me the other day from Iran to ask me how much I would charge for taking 30 people to France. I asked for 3,000 dollars per person but we couldn't agree. This is how it normally works. Those who know me, trust me, call me up. When I receive a call from Iran or Van, I phone the big smuggler who is the one that organizes the plane or the ship and tell him how many people I have and how much I will be getting for the job. I tell him I have so many people to go to Italy, for instance. If I make a deal for 4,000 dollars, 1,000 or 800 of this are mine. It depends on the situation. It makes no difference whether it is myself or the shipman that collects the money. If I collect it, I take my share and give the rest to the other guy. If he collects it, he gives me my share. If the smuggler I am in contact with does not have a ship ready, I call another shipman. Other middlemen like myself also work in the same way. They call up one by one the smugglers they know. There are a total of six to seven people who do this job anyway. For each trip, there is usually a wide mix of people, from Africans to Assyrian Iranians and from Kurdish Iraqis to Afghans.

I take over migrants in Istanbul. I don't care how they arrive in Istanbul, say from Van. The smuggler who makes the deal with me handles this part of the journey. My men place these people into hotels or houses that I have arranged and tell them not to leave the premises because they have to be there to move any minute the signal comes. It is not always possible for me to handle these people on my own. When there are five to ten people, this is ok, but if the numbers are larger, I need help. This is why I have men. After I take over the people in Istanbul, I guarantee that they will leave within one week. This is part of the 
deal. Nobody knows the time of departure, the route to be taken, or the means of transportation. Neither do I. When the news comes, I go and collect my passengers and bring them to the place of departure. It is my responsibility to take these people either to the airport or the harbour. For the flights, one of my men goes with the passengers, be it to Paris, Frankfurt, or Marseilles. After the border is crossed or the customs point passed, if the journey continues, my man hands these people over to the smuggler at the other side. If this is the last stop, he explains to them what to do, where to apply, and what to tell the officials.

I am an intermediary. There are hundreds of people who do the same kind of work. Bribery does not work at the lower levels but we have a brother up there at the top. With two photographs, all destinations are guaranteed. We handle the passport, visa, and etc.

You seem to be exaggerating the whole business. There aren't large organizations in this business. There is no need. If you provide me with two photographs, I guarantee you that I will drop you off at any point of your choice in the USA or in the UK. The US is 15,000 dollars, Australia is 12,000 dollars, and the UK is 8,000 dollars. Europe is between 4,000 and 6,000 dollars. I deal with approximately 1,000 to 1,200 people per year. If there is an accident during the process of smuggling, the responsibility is ours. In other words, if the person gets caught, his money does not go to waste. For the next try, we take him for free.

Our business works like this: before arrival, the middleman or the migrant himself contacts us. A deal is made. Upon arrival here in Istanbul, we place them into hotels and houses. Up to this point the responsibility is theirs. We guarantee them that they will leave the city within a week. At the very top there are smugglers who work internationally. They organize the transport either by sea or air. They also arrange the personnel at the customs, security, airport, and the harbour. In this way they ensure that the channels are open. There are people like myself who make the link between the migrants and the smugglers at the highest level. Let's say that from Istanbul to Brussels is 2,500 dollars. Included in this price are the passport and transportation expenses. If a visa is needed, we take an extra 600 to 700 dollars. I have dealt with a maximum of 300 people and a minimum of 20 people. It is difficult for people to put together this kind of money. I haven't come across prostitution but some of this money probably comes from drug trafficking.

As the above case shows, the middlemen take the migrants from the driver who brought them to Istanbul or another departure point to the chief organizer, who arranges for the final leg of the passage to the country of destination, which can be somewhere in Europe, Australia, or elsewhere. Alternatively, they look out for other illegal migrants to be handed over into the custody of the chief organizer who arranges the ship or the plane. In the ongoing operation of smuggling, one or two of the most powerful middlemen gain some specific status and start to play the role of chief organizers.

In return for a certain percentage, middlemen transfer customers to one another and they maintain an interactive and dynamic relationship with other inter- 
mediaries. For instance, when a ship prepares for takeoff, the intermediaries scout around for possible customers. However, they do not necessarily work with the same chief smuggler or chief organizer. If a ship is not prepared to take a large number of waiting migrants on board, the intermediary has no difficulty in entrusting them to another smuggler without causing undue tension between the intermediary and the chief organizer. Yet, if a chief smuggler were to arrange for another intermediary, by offering him large sums of money for instance, a competitive situation could arise which might culminate in mutual denunciation.

In the whole people-smuggling business, their role is probably the most important. It is the responsibility of the intermediary to arrange for accommodation of the migrants, of whom there may at times be more than 100 , for about a week either in hotels or rented flats, the owners of which are known to him, or in houses he owns. It is his job to ensure that within a week, which is the limit for Istanbul, arrangements and contacts are made for the migrants' departure to their final point of destination.

The intermediaries group the migrants according to their final destination and the means of transport to be used. For instance, a middleman may arrange for some to go to Italy by sea, for others to go by air to the UK, or to Germany by land, or even to walk or swim to Greece, and would have made the necessary plans and have already paid the bribes before they arrived. His continued presence in this business depends on this rate of success - one mistake and he may find himself out of work.

Such intermediaries provide their services to members of their own national or ethnic groups. Therefore, as a rule, migrants are brought into contact only with their own nationals, based on the understanding that a common national and ethnic background also ensures the middleman's reliability. For this reason, Turkish nationals have disappeared from the scene as middlemen, as they had been found to exploit the situation for their own benefit and to deceive the migrants in their custody. The pay of the middlemen can vary between US $\$ 800$ and $\$ 1,000$ per migrant.

\section{Landman, shipman, or airman}

Case representing shipman; male, Turk, primary school graduate, married, living in Istanbul; from face-to-face interview:

One-and-a-half months ago, Metin, a person called Laz, and I collected some migrants and tried to take them to Italy with a Russian ship. The ship was detained so we paid 46,000 dollars to set it free. However, on that day the weather was stormy and the ship could not reach the coast but had to wait in the open sea. The ship would wait for the storm to end, at least so we expected. Unfortunately, the ship left for Russia. We were left with the migrants. We were cheated. We started to wait. We thought about buying a ship to send the 
migrants. I have a man named Abdullah who knows all the intermediaries that collect people waiting to be smuggled. His nickname is Apo. There was also a captain who knew whether the ship was in good shape or not.

No matter where you are in Turkey, Istanbul is the centre for smuggling people outside the country. After having picked up goods from Italy, they are dropped off in Istanbul and on the way back to get more goods, smuggled people are placed inside the empty containers. There are agencies that are involved in this business. It is the intermediaries that find and collect the migrants and find hotels for them to stay in. The hotel owners know that these smuggled people stay in their hotels. Among the intermediaries there is even a police officer.

I asked the captain if the ship was any good. We decided it could be repaired and used for the transportation of smuggled people. It is more essential to arrange a ship because once the ship is ready there are always people waiting to be smuggled, even more than you would want. Apo knows around 100 to 150 intermediaries. The captain prepares the ship, Apo collects the people, and I look for a place from where we can load the travellers. We tried to bribe someone for Eminönü coast but it didn't work. Another friend, Y. T., suggested the coast of Muallim village in Gebze. He himself asked for 2 billion liras and the local authorities would be given 15 billion. The price was appropriate. Apo told me it would take about two days to get the migrants together and made an investigation into the surroundings of the area. We brought the migrants in two buses and placed them in certain houses in the village. They stayed there for two days. Around 5 o'clock in the morning the captain brought the ship to the coast and we brought the 449 people on board. We took care of the refugees' food and water needs. We got caught with the ship because we were noticed by the gendarmerie a short while after we left the coast. We tried to escape but the gendarmerie stopped us.

These smugglers intervene to organize the final leg of the journey. They are referred to as landman, shipman, or airman. Each is specialized in a particular form of transportation and not only organizes the corresponding means of departure but also arranges for the necessary bribes to be paid to the relevant people (e.g., port employees, police officers, customs officials).

The landman arranges the irregular border crossing. He basically finds guides and tries to arrange bribes to border officials. The cost of land passages does not often exceed US $\$ 500$. The airman provides illegal departures from the airports. This less frequent but most expensive procedure is often done either by using false documents or by bribing the border officials. This air-based arrangement often costs something around US $\$ 3,000$ to $\$ 5,000$. The shipman may either buy or rent a ship. If he rents one, he negotiates with the captain of the ship on the basis of the number of the migrants to be taken on board. The captain of the ship receives US $\$ 800$ to $\$ 1,000$ per migrant, but not before the ship has safely reached the final destination. 


\section{Other intermediaries, handymen, and other helpers}

Case representing driver; male, Turk, married, has two children, primary school graduate; from police reports:

I have been in the transportation business for many years. On the sixteenth of August, I came to Istanbul with a load of aluminium. After I unloaded the goods, I started waiting at the Ambarlar district of Istanbul for a new job. For two days there was no business. On the twentieth of the month, the sweeper in the neighbourhood, Mustafa, came to me with two Kurds. He said that for Çanakkale (a coastal city in Marmara Sea), he needed a truck for the transportation of porters and some belongings. He told me that there were 20 people who would be going as porters and he offered me 200 million liras. I requested from him 200 million to buy diesel oil and then another 100 million upon return. Together with Mustafa we went to a house in Günesli (a district of Istanbul). I opened the trunk of the truck and then we went to sit at a coffeehouse. When we went back in half an hour, everything had been loaded and the canvas had been properly stretched and closed. Mustafa gave me a simple plan of the road that I had to take.

I received many phone calls on the way from different people. They told me to change the route and follow the new route until I see a dock at the end of the road. I was told to unload the ship waiting at the dock and leave. I said I did not accept this, that I would not go to the dock, and that I would leave my load here. Then he said that he would send me a person who will take the truck to the dock, unload, and then bring me back my truck. Someone came by car. I handed him the truck at the turn of the road to the dock. He quickly came back with the back door open but the canvas on top still in place. I tidied the truck and got back on the main road. A while later the police stopped me and took me to the station.

This category of smugglers includes those who are involved in human smuggling but simply perform occasional ancillary and support functions. They come from various backgrounds and occupations, including officials and security personnel, and do not engage in smuggling on a regular basis, but occasionally help others by either finding hotels, houses, or land to temporarily accommodate the migrants, arranging for fake passports and visas, transport, or the coast from which to take off. Usually they live in the coastal regions of Turkey and own a house, land, or a boat of use to the smugglers. They are in this business for the money and intend to drop it once they have saved enough.

\section{HUMANTRAFFICKING ANDSMUGGLING: AN INTERNATIONAL MAFIA OR NETWORK OF LOCALS?}

It is often argued that people trafficking is a business dominated by organized groups (Di Nicola, 1999: 4; Shelley, 2001: (1) who expand their other smuggling operations to include human trafficking, shifting the respective risks and profits 
according to opportunities and the regions involved. As such, trafficking and other forms of organized crime are perceived as two sides of the same coin (Salt, 2000b: 43). Our own investigations in Turkey do not necessarily confirm the involvement of large mafia-style criminal organizations; rather a number of smaller, flexible groups seem to be active in this business on an opportunistic basis.

The people interviewed face-to-face, or whose statements to the police we were able to review, all acted at various stages of the illegal migration process, assuming different supporting or steering functions. We found no evidence of a hierarchical structure with a "godfather-like" figure at the apex. It seems that this is not a business organized on an international level, at least not as far as Turkey is concerned, and that it relies on a centralized command structure. Rather, a loosely cast network, consisting of hundreds of independent smaller units which cooperate along the way seems to be the case. It is the flexibility and adaptability offered by these that ensure the continuing activity and success of the larger operation since, even if one link along the chain should break, it can be immediately replaced without risking the disintegration of the whole. Thus, we prefer to think in terms of smaller, local and flexible organizations, rather than international, centralized organizations.

In general, illegal migrants are taken from city to city or from country to country via the "hand-to-hand" or "smuggler-to-smuggler" approach. The migrant who illegally crosses the border is handed over to another smuggler in the country of arrival and continues on his route. The smuggler, who speaks several languages and is sometimes the citizen of several countries, goes through one or more of the countries. Because of the large number of smugglers on the route, the smugglers in the country of destination are unaware of the smugglers in the country of departure. As noted earlier, given the smaller networks mostly based on national, ethnic, kinship, and friendship affiliations, smugglers are acquainted only with the smugglers from whom they receive migrants and those to whom they hand over migrants. They have no chances of meeting and relating to other smugglers who make up the remaining pieces of the larger chain. This can cause the chain to become disrupted momentarily, but the missing link is quickly replaced and, since forward and backward linkages are usually not known to each other, they are not put at risk by any depositions to the police when apprehended. These links are extremely adaptable and as the situation requires can be called upon depending on the transport needed and the particular arrangements to be made for the onward journey. These locally organized networks working out of cities on the western coast of Turkey (e.g., Istanbul, Izmir, Çanakkale) are specialized in particular aspects of the trafficking and smuggling process, e.g., the forging of passports and of visas. They know the people able to provide or arrange temporary accommodation for the migrants and the necessary means of transport, or they know the officials who need to be contacted and/or bribed at any time to ensure the smooth functioning of the illegal 
undertaking. They all interact at various stages along the smuggling process, competing and cooperating with one another and steadily expanding the geographical and functional range of the smuggling network. They carry out their activities not as members of a large, central organization for illegal migration, but as independent pieces, which form only a small part of the larger chain.

These groups are held together by loyalties forged through their mutual involvement in a range of illicit activities with each depending on the other to remain beyond the reach of the police. They include people who have themselves been, and might indeed still be, illegal migrants (one person interviewed had been living in Istanbul for 16 years with a false ID card, and was working as a merchant and middleman without a residence permit). They are familiar with the routes to be taken and serve as guides for others. Usually they deal with migrants from their own ethnic or national background and are instrumental in establishing contacts between smugglers and migrants from their home regions because they are familiar to both. Migrants know how to contact them before leaving their country and on arrival in Turkey. Thus, the middleman is already informed about the number and composition of migrants to be expected and accommodated, and where they will go, together with the necessary arrangements to be made for false passports and visas depending on their routes and destination.

Modern communication technology in the form of cellular phones and pre-paid cards has greatly facilitated the business of smuggling and trafficking, and helps to establish and easily maintain long-distance contacts between the smugglers, and the smugglers and the migrants, without leaving a traceable imprint. Thanks to such international communication links, various outposts of the network, no matter where they may be, are able to establish contact and exchange information, which helps them to adapt their strategies and plans according to the prevailing situation. The following anecdote illustrates this. Late in June 2001, two women from Eritrea who were under arrest in Marmara Ereglisi, a coastal town on the Marmara Sea, were interviewed. Two weeks later they called to notify the interviewers that they had made it to Italy. After their arrest in Turkey, they had been placed on a bus to be removed from the country. While crossing the Bosphorus Bridge with 42 other migrants, they had managed to escape. Despite the fact that they had no money on them, within two weeks they were placed on a ship to Italy and reached their final destination. This must be the result of the "insurance" guaranteed by smugglers to illegal migrants who come across "occupational accidents" on the way to their country of destination, as well as the reliance on modern means of communication.

\section{THE TRANSFER AND CHANNELLING OF FUNDS}

Although still less than the amounts of money involved in drug trafficking, the profits from migrant smuggling are very high. The transfer of funds by the 
smugglers via a complicated system spanning several and cities and regions, based on ethnic affiliations and connections is a complex matter. Iraqi smugglers use the method of a trusted third party as cashier in their dealings with the migrants. As mentioned previously, interpersonal trust among the smugglers and traffickers and the migrants seems to be a key factor that makes the operation of smuggling and trafficking possible. Once the migrant has reached his destination and has communicated a previously agreed on secret code, the smuggler will receive his share. Smugglers of other nationalities and ethnic groups prefer to be paid in advance. A different method applies in the case of Afghan migrants whose property is confiscated by the smuggler who himself then finances the migrants' journey to his destination. However, often the principal practice is payment in advance. Usually no money is found on illegal migrants and smugglers when they are caught, which may be taken to indicate that money changes hands between the migrant and the smuggler prior to the journey.

If there is no case of a "cash in advance" type of arrangement, the illegal migrants do not make the arrangements for their country of destination with the smugglers in their country of departure. Migrants generally cross borders with the help of local smugglers and the money is paid to each smuggler for the border crossing or the smaller portion of the route taken. For instance, a migrant who pays 150 dollars for the journey from Iran to Turkey, pays another smuggler 250 to 300 dollars for the trip from Van to Istanbul (the amount increases if fake documents are included). Extra money is again paid for the trip from Istanbul to a country in Europe or elsewhere. Yet, this method of payment has other risks. There are plenty of cases, for instance, in which migrants who carry money or belongings are robbed.

In border crossings, if arrangements are made between smugglers, the smuggler who hands over the migrant to the next smuggler gives a share of the total money previously paid by the migrant to the initial smuggler. This procedure is repeated for other arrangements made along the way. The money, shrinking as it goes further, travels the same route as the migrants.

\section{CONCLUSION}

Empirical research on regional or country cases of people smuggling, such as in Eastern Europe, the Balkans, Russia, and China, has deepened our understanding of the complexities of human trafficking and smuggling. Generalizations drawn from the existing literature on human trafficking and smuggling include: they are controlled by criminal syndicates; they lead to situations of bonded labour and virtual slavery; and they involve kidnapping and forced exploitation, particularly of women and children (IOM, 2000: 9). 
Our findings on human smuggling in the Middle East and Turkey differ considerably from previous studies conducted in the other parts of the world. We argue that in order to gain a better understanding of the causes and consequences, the magnitude, and the international ramifications of human smuggling in our region of study, it is necessary to realize that the smugglers do not necessarily constitute a centralized criminal organization. Generally speaking, independent individuals or groups specialized in particular aspects of the operation combine and coordinate their efforts at various stages along the smuggling process. They normally have access to the latest telecommunications technology such as mobile phones and can change and adapt their strategies rapidly depending on new situations, in terms of reinforced border controls along particular borders or regarding the most profitable means of transportation. This study did not conclude that people smuggling was either similar or even closely linked to drugs or arms smuggling organizations, whose structure and method of operation appear more centralized and hierarchical compared to those of people smuggling. ${ }^{8}$

Even though they are not supported by a centralized organizational system, smugglers nevertheless run their operations effectively with the help of and ubiquitous recourse to modern communications technology, which allows them to interact swiftly and globally to exchange pertinent information, without leaving tell-tale traces. They work through a string of contacts including people able to supply various services such as accommodation and local transport, forgers of documents, corrupt officials, transport agencies, and many more. Many of these networks are based on ethnic ties.

For the duration of the smuggling operation, from the point of departure to destination, the link between migrants and smugglers is held together by their reciprocal interest, on the one hand, and the unequal power relationship on the other: the migrants' dependence on the know-how and methods used by the smuggler and the latter's retention of power and manipulation, welded together temporarily by the same objective - to reach the point of destination. It is here that the smuggler takes his reward and pockets the profits, and the migrant receives his opportunity to make a better life for himself. Also integral to this process is trust and personal knowledge and the need of smugglers to deliver a service.

However, given the growing numbers of migrants and the burgeoning demand for passages from all corners of the world, the smuggling business perhaps can no longer rely on ad hoc operations supported by the punctual recourse to and intervention of individual collaborators for services along the way. Perhaps only parts of the operations will become more centralized, such as documents and air and sea transportation. Recruitment and delivery to central points for movement to points in the West may become more centralized, as they seem to be elsewhere. Ultimately, smuggling of people, like other smuggling, may be a mixed 
operation of small-time operators for recruitment and retail distribution, and large-scale enterprises for wholesaling and shipment. Smuggling, in all ages, seems to have been endured because of its adaptability.

\section{NOTES}

1. For the studies that mainly elaborate on the details of the criminal size of trafficking and smuggling, see various reports of the International Organization for Migration (IOM).

2. See again various reports of IOM.

3. As widely recognized, irregular migration and asylum seeking are two different issues, but their similar vulnerability to the trafficking and smuggling activities makes them interrelated and comparable, see for instance Koser (2000).

4. It is expected that a study will be published by IOM focusing mainly on irregular migration flows and human trafficking and smuggling issues in Turkey in 2003.

5. This project, "Bridging the Middle East and Europe: Transit Migration Flows in Turkey", was funded by the Population Council through the MEAwards Program, 1999-2002.

6. This project, "Irregular Migration Flows through Turkey", was funded by IOM in 2001-2001, as a part of the IOM Migration Research Series on Irregular Migration, Human Trafficking and Smuggling.

7. This project "A Reassessment Project for Data Collection on Immigration to Turkey", was funded by the United Nations Population Fund (UNFPA) and Turkish Academy of Science (TAS) in 2002.

8. In fact, the security authorities interviewed in this study have also repeatedly and overwhelmingly emphasized the differences between drug trafficking and human trafficking.

\section{REFERENCES}

Di Nicola, A.

1999 "Trafficking in immigrants: a European perspective", paper presented at the Colloquium on Cross-border Crime in Europe, 27-28 September, University of Trento, Prague.

Graycar, A.

2000 "Human smuggling", unpublished paper, Australian Institute of Criminology, Canberra.

Içduygu, A.

2000 "The politics of international migratory regimes: transit migration flows in Turkey", International Social Science Journal, 165: 357-368.

2001 "Turkey and the International Migration", unpublished SOPEMI report for Turkey, Ankara. 
Içduygu, A., and E.F. Keyman

2000 "Globalization, security, and migration: the case of Turkey", Global Governance, 6: 383-398.

Içduygu, A., and T. Ünalan

2002 "Tides between Mediterranean shores: undocumented migration in the south of Europe", working paper no.7, Hacettepe University Institute of Population Studies, Ankara.

IOM (International Organization for Migration)

2000 Myths and Realities of Chinese Irregular Migration, IOM, Geneva.

Juhász, J.

2000 "Migrant trafficking and human smuggling in Hungary", in International Organization for Migration (Ed.), Migrant Trafficking and Human Smuggling in Europe: A Review of the Evidence with Case Studies from Hungary, Poland and Ukraine, IOM, Geneva: 167-232.

Kirisçi, K.

2001 "Refugees of Turkish origin: 'coerced immigrants' to Turkey since 1945", International Migration, 34(3): 385-412.

Koser, K.

2000 "Asylum policies, trafficking and vulnerability", International Migration, 38(3): 91-111.

Okólski, $\mathrm{M}$.

2000 "Illegality of international population movements in Poland", International Migration, 34(3): 57-89.

Pugh, M.

2001 "Mediterranean boat people: a case for co-operation?", Mediterranean Politics, 6(1): 1-20.

Salt, J.

2000a "Note from the guest editor", International Migration, 38(3): 3-6.

2000b "Trafficking and human smuggling: a European perspective from Asia", International Migration, 38(3): 31-56.

Schloenhardt, A.

1999 "The business of migration: organised crime and illegal migration in Australia and the Asia-Pacific region", paper presented at the University of Adelaide Law School, Adelaide.

Shelley, L.

2001 "Trafficking and smuggling in human beings", paper presented at the George C. Marshall European Center for Security Forces Conference on Corruption within Security Forces: Organized Crime as a Threat to National Skeldon, R. Security, 14-18 May, Garmisch.

2000 "Trafficking: a perspective from Asia", International Migration, 38(3): 7-30. SMOFA (Swedish Ministry of Foreign Affairs)

2001 Trafficking in Women and Children in Asia and Europe: A Background Presentation of the Problems Involved and the Initiatives Taken, Ministry Tailby, R. of Foreign Affairs, Department for Asia and the Pacific, Stockholm.

2001 "Organised crime and people smuggling/trafficking to Australia", paper in trends and issues in crime and criminal justice, Australian Institute of Criminology, Canberra. 
UNICRI (The United Nations Interregional Crime and Justice Research Institute) and AIC (Australian Institute of Criminology)

2000 "Human smuggling and trafficking: a desk review on the trafficking in women from the Philippines", unpublished paper for the $10^{\text {th }}$ United Nations Congress on the Prevention of Crime and the Treatment of Offenders, Vienna. 


\section{COMMENT S'Y PRENNENT LES PASSEURS ET LES TRAFIQUANTS POUR FAIRE FRANCHIR CLANDESTINEMENT LES FRONTIERES DU MOYEN-ORIENT PAR LES MIGRANTS? LES RESULTATS D'UN TRAVAIL DE TERRAIN EN TURQUIE}

Cet article résume les tendances, les problèmes, les activités et les acteurs principaux concernant les méthodes de la traite et de l'introduction clandestine de migrants au Moyen-Orient. Il pose pour prémisse que ce ne sont pas les filières organisées de type mafieux et hiérarchisé qui sont à la base de la traite des êtres humains dans la région, mais plutôt des réseaux articulés de groupes individuels opérant de façon indépendante. Les témoignages empiriques disponibles font avant tout ressortir que l'étude approfondie des divers aspects de la traite des êtres humains et de leur introduction clandestine est une tâche délicate et que, si l' on veut se fixer des priorités en termes de collecte et d'analyse de données sur de telles activités, il faut au préalable avoir une idée bien précise des informations à recueillir et de la manière dont elles peuvent être obtenues. Etant donné le caractère particulièrement sensible des problèmes que sont la traite et l'introduction clandestine de migrants, il n'existe pas de pratique simple de recherche qui puisse répondre à toutes ces préoccupations. C'est pourquoi notre analyse ne donne qu' une explication partielle de la nature complexe de ces deux processus au Moyen-Orient. Les données qui sont ici utilisées constituent, à notre connaissance, les premières données primaires, fiables et représentatives concernant les trafiquants et les passeurs, dans la mesure où elles émanent directement des propos tenus par les trafiquants et les passeurs interrogés.

Le travail de terrain que nous avons effectué en Turquie au cours des cinq dernières années révèle que la forme actuelle des pratiques de traite et d'introduction clandestine de migrants dans la région est le produit d'interactions particulièrement complexes entre des individus et des groupes opérant au plan local, sur quoi vient se greffer l'action simultanée et consécutive d'une palette de facteurs interdépendants, au nombre desquels il faut citer les relations de confiance entre les trafiquants et les passeurs d'un part et les migrants d'autre part, et l'existence de réseaux fondés sur l'appartenance nationale, l'origine ethnique, la parenté et les liens d'amitié, qui s'étendent des pays d'origine aux pays de destination de par le monde, en passant par les pays de transit. Cette étude a confirmé que le caractère des activités de traite et d'introduction clandestine au Moyen-Orient était très différent de celui des activités similaires se déroulant dans d'autres régions du monde. Néanmoins, la conclusion est qu'il n'est pas possible de faire abstraction, lorsqu'on examine de telles questions, des aspects relatifs à la répression du crime et aux droits de l'homme. 


\section{¿CÓMO OPERA EL TRÁFICO Y LA TRATA DE PERSONAS \\ A TRAVÉS DE CRUCES IRREGULARES DE FRONTERAS EN EL MEDIO ORIENTE? PRUEBAS DESDE EL TERRENO EN TURQUÍA}

Este artículo resume las principales tendencias, cuestiones, interlocutores y actividades relacionados con el funcionamiento y extensión de la trata y el tráfico de personas mediante cruces irregulares de fronteras en el Medio Oriente. Su premisa es que en lugar de la participación de la jerarquía mafiosa del hampa, hay redes globales articuladas de grupos locales independientes que operan y se ocupan esencialmente de la trata y el tráfico de seres humanos en la región. Las pruebas empíricas disponibles demuestran que todo lo referente a la trata y el tráfico es delicado y que cualquier consideración de las prioridades para el acopio de datos con miras a su análisis debe comenzar con una idea clara de la información necesaria y de cómo obtener dicha información. Habida cuenta del carácter altamente sensible de las cuestiones de trata y tráfico, no existe una práctica de estudio simple que pueda abarcar todas estas preocupaciones. En este contexto, nuestro análisis sólo ofrece explicaciones parciales al carácter complejo del tráfico y trata de personas en el Medio Oriente. Los datos utilizados en este artículo constituyen, a nuestro entender, la primera información primordial, fidedigna y representativa sobre traficantes y contrabandistas, puesto que provienen directamente de narraciones de los traficantes y contrabandistas entrevistados.

El trabajo realizado en el terreno en Turquía durante los últimos cinco años, apunta a un patrón en curso de trata y tráfico de seres humanos en la región resultante de interacciones bastante complejas entre las personas y grupos que operan localmente, con la intervención simultánea y secuencial de toda una serie de factores, incluidas a saber, relaciones interpersonales de confianza entre traficantes, contrabandistas y migrantes y la existencia de redes nacionales, étnicas, de parentesco, amistosas en plena expansión en los países de origen, tránsito y destino en todo el mundo. Este estudio ha confirmado que la naturaleza del tráfico y la trata en el Medio Oriente es bastante diferente de actividades análogas en otras partes del mundo. Ello no obstante, el estudio concluye que no hay que dejar de lado estas cuestiones desde la perspectiva de la justicia penal $\mathrm{y}$ de los derechos humanos. 